\title{
Organizational Justice: The Way it Works
}

\author{
JUNAID ATHAR KHAN \\ PhD Scholar, Institute of Business Studies and Leadership \\ Abdul Wali Khan University, Mardan \\ junaid@awkum.edu.pk \\ DR. SHAHID JAN \\ Associate Professor, Islamia College Peshawar
}

\begin{abstract}
Organizational justice has the potential to work in order to extract benefits for organizations and employees alike. If it implemented in full spirit will eventually improve commitment level improved job performance, more helpful citizenship behaviors, improved customer satisfaction, and diminished conflict. We demonstrate the management of organizational justice with some suggestions for building fairness into widely used managerial activities. These include hiring, performance appraisal, reward systems, conflict management, and downsizing.
\end{abstract}

Keywords: Organizational Justice, Performance, Hiring, Appraisal

\section{Introduction}

It is the organizational justice which has the latent power to produce desirable benefits for organizational as well as employees. Closer to that (Ashforth \& Humphrey, 1995)have then the view that Justice is beneficial in the enhancement of commitment and trust. Moreover job performance and customer satisfaction also improve with the establishment of organizational justice. Thus it results in diminished conflict and useful citizenship behaviors. In this article (Barley \& Kunda, 1992) proposes some suggestions to manage the organization justice. Through these suggestions organizations will be able to build fairness in their managerial activities. These different activities are hiring process, performance appraisal, conflict management, reward systems and downsizing. Pfeffer \& Sutton (2006) explains that importance of justice is also evident from a quotation where David Webster is of the opinion that the greatest aim of man is justice. Moreover (Miller\& O'Leary, 1989)admits that business organizations are considered as mere economic institutes. Implicitly or explicitly this prudent opinion gives the idea of the employers having their workforce. Many organizations give importance to quid pro quo exchange. It means one thing in exchange for another.

Thus these institutions prefer the monetary payment for the accomplishment of different important and inevitable tasks. These tasks are performed by the employees and their worth is judged by a supervisor. All such kinds of assessments are based upon the expertise and special knowledge of managers. Personal financial gain is the sole motivation for an employee to work. In this regard merit pay is effective to great extent. Through following this principle downsizing the size of workers and elimination of idle workers is possible. This rational model is more effective for the gain of the firms through such cost reductive measures. 
It is further been noted that no doubt businesses are the economic institutes. All their activities revolve around the financial gain or loss. But these organizations are not solely the economic institutes. If they will be considered only for the economic perspective, it can have different hazardous side-effects. Attention must be paid to economic affairs but the sense of duty and other ethical obligations are more important than economic matters. Sometimes merit pay is ineffective and downsizing is hazardous for the organization in the long run. Through organizational justice people can work together effectively. Contrary to it, injustice is destructive to great extent. It retards the growth of such institutions.

In this article details are given on organizational justice. The main emphasis is how to achieve practical ends through it. Here in this paper Justice along with its three core dimensions is also discussed. These dimensions are distributive, procedural and interactional. After these dimensions the importance of justice is provided through different criterion variables. After the nature of justice is understood it will be easy to explain the adoption of justice in the workplace. Here the main focus is on the management of the organizational justice. To achieve this end different techniques and suggestions are provided in this paper (Pfeffer \& Sutton, 2006).

\section{Literature Review}

\subsection{Organizational Justice (Prescriptive Verses Descriptive)}

Skitka, Winquist and Hutchinson(2003) explained that concept that Long time ago the management scientists, social commentators and philosophers used to write in this respect. Among them the ancient Greeks are worth-mentioning. They prescribed rules in every field and determined what were just. They used to logically determine these prescriptive rules. Hence these rules are called prescriptive approaches. They have prescribed such rules in the field of business as well. Accordingly Cohen-Charash and Spector (2001) further elaborated that Management scientists are different from the ancient traditional philosophers. They use descriptive approach. They do not determine rules and set standards but they observe people's attitude in this regard. Hence they prefer what society considers being just. Through this observation they formulate the rules. Thus organizational justice is an individual's evaluation about what is ethically right. It is essential for the managers whenever they produce some sort of justice the perspective of employees must be considered. Unfortunately this approach is not strictly followed in the workplace.)

\subsection{Reasons of Employees' Sensitivity Towards Justice}

According to managers justice is the desirable outcome in the mind of an employee. Such managers are confused themselves. They don't know the difference between outcome justice and outcome favorability. Outcome justice is the assessment of moral decency while the latter is the assessment of an individual's value or worth. To attain what is desired is really important but an individual is sensitive to many other things as well. Thus following are the reasons due to which justice is important for the people (Cropanzano, Rupp, Mohler, \& Schminke, 2001).

- Benefits in the long- run

- Social concerns

- Ethical concerns 


\subsection{Benefits in the Long Run}

In the view of Krehbiel and Cropanzano (2000)When people apply for the jobs in different institutions, they enter there for a considerably long time period. They need to predict of their future treatment by the respective organization. Employees are in favor of justice. It is due to justice that the control model is workable. Through this model, employees can foresee as well as control their possible future benefits. It is possible only through the presence of justice through which employees see their bright future(Krehbiel \& Cropanzano, 2000). Folger (2001) made it evident in this model that people are usually motivated by financial and economic interests. People also like fairness. Employees become happy and satisfied when they perform well. However if the employees get success through unfair means or cheating, they often feel guilty for their behavior. It suggests that people can react and identify injustice even it is beneficial for them personally.

Spencer and Rupp (2006) mention that Sometimes people mold particular rules to fulfill their desires. According to some management scientists pay satisfaction is not very closely related to pay justice. If due to justice they were getting high incomes, the association between the two would be strong enough. For instance evidence shows that many individuals get low income as far as fair process prevailed in the institutions.

\subsection{Social Concern}

Ellard and Skarlicki (2002) provided that everyone knows human beings are the social animals. They want to be valued and accepted by other members of the society. At the same time they want to be safe from the exploitation at the hands of others. Same is the case with the employees in an organization. They wish to be praised and respected by those in low rank as well as those in high rank.If there is just behavior and treatment in a particular institute, group-value-model informs the employees that they are esteemed and respected by others in their surroundings. The risk of mistreatment is also very less.

On the other hand (Tyler \& Blader, 2000) suggests that apart from its benefit, just treatment has also got many disadvantages. It can create problems for the institute as well. For instance, those employees who are very loyal to the company and when they are expelled out of the company through downsizing, they become hurt intensely. Thus if workers are treated unfairly, they can be saved from intense harm.

\subsection{Ethical Concern}

In the case of Ethics (Goldman, 2003) Proposes that workers are sensitive to justice due to their belief. According to their belief, justice is ethically appropriate way to treat others with. Sometimes a worker witnesses the unethical behavior with his coworker and he also gets stress from it. Hence in such a case injustice may result harm to a workgroup.

\subsection{Components of Justice}

Folgers (2001) and Ambrose and Schmink(2007) referred to three components of justice namely; distributive justice, procedural justice and interactional justice have found and analyzed. All these three components are closely connected. They are also called the components of fairness. Generally they work together. To promote justice particularly in the workplace, one should deal with these components in detail. These components must be treated separately. Through such approach each aspect of the components will be revealed. 
(Milkovich\& Newman, 2005) explains first component because it concerns with the allocation of outcomes. These outcomes are distributed differently. Such distribution is called distributive justice. Not all the workers are paid equally. They are paid according to their competency level. Sometimes there is just distribution in an organization. In such case promotion of a qualified person happens. Unfortunately other times there is lack of just distribution.

\subsection{Equity Theory}

It is a theory about just distribution. However earliest theory about just distribution has presented by Aristotle in Ethics. In this theory he has given the details about just distribution. According to him such distribution is something proportionate or equal ratios. This theory led to the equity theory which has presented by Adams (1965) it is represented with the help of the following equation.

\section{$\mathrm{O} 1 / \mathrm{I} 1=\mathrm{O} 2 / \mathrm{I} 2$}

Outcome is represented by $\mathrm{O}$ while input is represented by I. It tells us the relation between $\mathrm{O}$ and $\mathrm{I}$. O1 is the outcome an employee gets and I1 is the input he contributes to the company. If there is no standard, then this relation is of no use. For this purpose outcomes (O2) and inputs (I2) of referents are examined. Hence relation between outcome and input is found out in this way. When both the ratios are not the same, then it is not in favor of an employee. As a result they feel uneasy and dissatisfied. Through this equation they can balance their input according to their outcome. For more detail if an employee is underpaid, he might decrease input by a particular amount (Martin \& Harder, 1994).

Some predictions are resulted from this equation. However few of them are unclear. For instance a worker will be satisfied even if he is underpaid as compared to the other worker in the same workplace. It is so because he is contributing less to the respective organization as compared to him. On the other side a worker will not be satisfied if he is paid less as compared to his co-worker while the two are contributing equally to the institute. These consequences are very rare but they fit to this equation.

Over-reward effect is another prediction of this theory. It happens when both the ratios are not the same in a worker's own favor. In such case the workers are overpaid. As a result he then must increase his input to attain the balance. For most of the times these balances are not brought in the input. Thus workers face distribution injustice in this case. It has a very bad impact on the workers as well as on organizations. Adams (1965)

\subsection{Recent Advances in Distributive Justice:}

According to Martin and Harder(1994) many advances have taken place in this component. Hence there is not mere the equity theory to provide details about the distributive justice. Besides equity theory three rules have formulated. They contribute to distributive justice to great extent. They are equality, equity and need. These rules are designed on the basis of Aristotle's famous philosophical thoughts. According to his saying people want to be equally treated like the remaining all the people (equality), like few other people (equity) and treated similar to no one (need). To find combination in these three rules, following three suggestions can be proved helpful. Firstly, it is important to know one's goals. In this case equity provides one with rewards for one's high performance. While equality build a spirit or make one to inspire from other's high performance. 
Kim and Mauborgne (2005) have shown institutions balance by combining equality as well as equity. Here in this case workers are provided with their minimum and basic rewards as well. Due to this practice they become motivated to earn more and get greater rewards. Other individuals also get inspired in the workplace. They also start to improve their performance. In this way outcome is also in accordance with input. Thirdly, awards must be given according to these three instrumental rules. Provision of awards according to equity rule is good in one way i.e. in form of money but it is not good in other way i.e. socio-economic facilities and satisfaction on part of the employees. For instance workers should provide with comfortable environment and private parks. It will also be harmful to give them an effect that the distribution is equal and just.

\subsection{Procedural Justice}

This kind of justice does not refer to outcomes specifically but it concerns with the means or process through which allocation of outcomes occurs. Certain rules have established for this purpose. Fair-Process effect has established by Leventhal (1980) with the help of his colleagues. According to this effect the process of allocation of outcomes must be just and correct in order to avoid injustice distribution. Kim and Mauborgne (2005) have elaborated different qualities of managers in their combined work. They are of the opinion that a loyal manager must confirm whether headquarter or the department involve in allocating outcomes has adopted the just procedure or not. In such a case employees will trust their manager. The case will be vice versa if the manager will not be loyal to his employees. Hence Karuza \& Fry (1980) considered important for an organization to adopt just procedure of distribution. If the employees observe this loyalty, they show more willingness and greater loyalty in performing to the institute.

\subsection{Interactional Justice}

Skarlicki and Latham (1996) believed that this form is the simplest of all the components. It concerns with person to person treatment. Interactional is a person who shares just information appropriately. There are two kinds of interactional justice. The first one is informational justice and the second one is interpersonal justice. Informational justice means that one must provide truthful and adequate information. On the other hand(Colquitt, 2001) relates it to dignity and respect. It stresses upon transaction between two persons or groups. Employees get inspired from the manager in this regard. Hence managers are the role models for them. For the purpose of just interaction, managers and employees must be provided with training. Researchers have also shown that the trained leaders perform better as compared to untrained leaders.

\subsection{Working of Justice}

The negative impact can be overcome if only one component of justice is maintained. For instance, if there is lack of distributive as well as procedural justices while interactional justice is there in the workplace. In such a case, the situation can be controlled with only the prevalence of one kind of justice. Justice has got tremendous importance for the organization as well as employees success. It builds and develops commitment and trust. It improves job performance. It also guides the employee's institutional citizenship attitudes. It develops loyalty and satisfaction on the part of customers. In short its role is not negligible. It contributes to organizations from various aspects. 
Numerous research have made to investigate the just and unjust treatment in the workplace, however there is difference of opinion. Each of the finding will be looking individually. Trust is the most vulnerable position on either side of the party. According to (Colquitt, 2001) that all the three components of Justice bring trust but there is a strong association of procedural justice with trust that is 0.60 , moreover commitment of employees is also high towards employer with procedural justice. Contrary (CohenCharash\& Spector, 2001) measured weak correlation ranges from 0.37 to 0.43 .

\subsection{Fairness Improves Job Performance}

As Learner (2003) observed that performance is referring to fulfill the given task with in prescribe time. The effectiveness of workplace performance can be improve by justice and very helpful in field comparatively in the laboratory work environment. Cropanzano (2002) examined that when leaders are treating their subordinates with interpersonal justice where they are able to maintain higher quality of relationship. This strong relationship motivates employees in less expensive manner by not depending upon pay and other benefits they are expecting in reward of good performance.

\subsection{Justice Promotes Organizational Citizenship Behavior Among Employees}

Organ (1988) found during several studies that justly treated employees can adjust easily in the workplace, keeping good behavior towards other during duty hours and even comply good attitude beyond duty hours too. Considering the case of temporary workers Liden, Wayne, Kraimer, and Sparrowe (2003) surveyed contingent workers who were given appointment to do job in manufacturing firm through agency. It was discovered that employees receiving procedural fairness from manufacturing firm were performed more OCB, however on the other hand procedural justice received by employment agency to these workers did not enhanceOCB.

\subsection{Positive Approach of Job Candidates Regarding Organization}

Bauer at el. (2001) recommends that fairly treated applicants form positive attitude towards organization whereas when employees feel unjustly taking the help of litigation process as a remedy to get their right. Research suggests that fairly hiring process provides strong footing and trust when applicants become employees.

\subsection{Justly Balance Reward System Meets Multiple Goals}

Pfeffer and Langton (1993) examined the study of academic faculty that equity allocation result in less satisfaction and less collaboration with colleagues. Because paying same to every one reduces productivity in total. Equality distribution of reward boost up employees motivation.

Mcfarlin and Sweeney (1992) surveyed 600 bank employees and experienced two factor model in action that is distributive justice is not contributing well comparatively with procedural justice and interactional justice in pay satisfaction and job satisfaction

\subsection{Management: When you do not have to win.:}

Schoorman and Champagne (1994) tells that conflict is most difficult situation to tackle. In most of the cases manager(s spending more time in conflict resolution because settlement can be listen on behalf of both the parties, which is called arbitration. Which ultimately cause distributive injustice but on the other hand (Goldman, 2003) suggests during settlement any factor of justice available can make situation improved by reducing unhappy destructive outcome. There is a saying of (Cropanzano, 2002) "If you cannot give people the outcome they want, at least give them a fair process" 


\subsection{Downsizing Softening Hardship}

Hiring, reward system, and conflict resolution are the routine matters in large organization can be overcome if Justice is taken into account. (Richman, 1993) put forward that the most serious practice among all is downsizing, which is called a cost cut strategy. The layoff can be best handled by interpersonal justice so that the workforce know why downsizing is necessary.(Brockner et al, 1994) interviewed the victims of downsizing among all $66 \%$ went for litigation, $16 \%$ were those who felt that they were treated justly. These were impressive findings when managers admitting guilt through apology. In simple words result suggests apology is the procedure of interpersonal justice which reduces the risk of litigation and promote the feeling of justice.

\subsection{Performance Appraisals: Keeping Score Impartially}

The performance appraisal system often affected by political concerns and in social context in which it is conducted deterioratethe performance evaluation process assigning reward on the basis of this process (Levy \& Williams, 2004). However (Smither, London, \& Reilly, 2005) conducted Meta-analysis on 27 field studies found that employee when participated in the performance appraisal had voice were motivated and satisfied because they could see the process fair and better.

Organizational justice research provides paradigm to understand performance Cropanzano (2001) called it a due process approach to performance appraisal. It has the following three main elements

1- Adequate Notice: Letting people to know in advance that what would be criteria of appraisal followed by feedback.

2- Hearing employees personally after a feedback providing a chance to interpret their self even in the disagreeing situation.

3- Standards for judgment should be accurate in order to keep process free of political influence.

\subsection{Concluding Thoughts}

Looking to the two sides of justice just like a coin. The negative side represents the absence of justice, damaging environment and low morale eventually low performance of organization (Viswesvaran \& Ones, 2002).

On the positive side justice can nurture unfortunate outcomes by allowing employees to give respect and maintain collegial trust among each other (Goldman, 2003)

Culture of justice gain strong business opportunity as well as strong employee commitment which providing edge of competition. In this paper different HR practices have been examined through the help of different elements of justice enables managers to take tough decisions in a smooth manners.

\section{References:}

Adams, J. S. (1965). Inequity in social exchange. In L.Berkowitz (Ed.), Advances in experimental Social psychology, Vol. 2, pp. 267-299. New York: Academic Press.

Ambrose, M. L., \& Schminke, M. (2007). Examining justice climate: Issues of fit, simplicity, and ontent. In F.Dansereau\& F. J. Yammarino (Eds.), Research in multilevel issues, Vol. 6, pp. 397-413. Oxford, England: Elsevier. 
Ashforth, B. E., \& Humphrey, R. H. (1995). Emotion in the workplace: A reappraisal. Human Relations, 48, 97-125

Barley, S. R., \& Kunda, G. (1992). Design and devotion: Surges of rational and normative ideologies of control in managerial discourse. Administrative Science Quarterly,37, 363-399.

Bauer, T. N., Truxillo, D. M., Sanchez, R. J., Craig, J., Ferrara, P., \& Campion, M. A. (2001). Applicant reactions to selection: Development of the selection procedural justice scale (SPJS). Personnel Psychology, 54, 387-419.

Brockner, J., Konovsky, M., Cooper-Schneider, R., Folger,R., Martin, C., \& Bies, R. J. (1994). Interactive effects of procedural justice and outcome negativity on victimsand survivors of job loss. Academy of Management Journal,37, 397-409.

Cohen-Charash, Y., \& Spector, P. E. (2001). The role ofjustice in organizations: A metaanalysis. Organizational Behavior and Human Decision Processes, 86, $278-321$.

Colquitt, J. A., Conlon, D. E., Wesson, M. J., Porter, C. O. L. H., \& Ng, K. Y. (2001). Justice at the millennium: A meta-analytic review of 25 years of organizationaljustice research. Journal of Applied Psychology, 86, 425-445.

Cropanzano, R., Prehar, C. A., \& Chen, P. Y. (2002). Using social exchange theory to distinguish procedural from interactional justice. Group and Organizational Management, 27, 324-351.

Cropanzano, R., Rupp, D. E., Mohler, C. J., \& Schminke,M. (2001). Three roads to organizational justice. In J.Ferris (Ed.), Research in personnel and human resources management, Vol. 20, pp. 1-113. Greenwich, CT: JAIPress.

Ellard, J. H., \&Skarlicki, D. P. (2002). A third-party observer's reactions to employee mistreatment: Motivational and cognitive processes in deservingness assessments. In S. W. Gilliland, D. D. Steiner, \& D. P.

Skarlicki (Eds.), Emerging perspectives on managing organizational justice (pp. 133158). Greenwich, CT: Information Age Publishing.

Folger, R. (2001). Justice as denounce. In S. W. Gilliland, D. D. Steiner, \& D. P. Skarlicki (Eds.), Research in social issues in management, Vol. 1, pp. 3-33. New York: Information Age Publishing.

Goldman, B. M. (2003). The application of reference cognitions theory to legal-claiming by terminated workers: The role of organizational justice and anger. Journal of Management, 29, 705-728.

Kim, W. C., \& Mauborgne, R. A. (1991). Implementing global strategies: The role of procedural justice. Strategic Management Journal, 12, 125-143.

Krehbiel, P. J., \& Cropanzano, R. (2000). Procedural justice, outcome favorability, and emotion. Social Justice Research,13, 337-358.

Leventhal, G. S. (1980). What should be done with equity theory? New approaches to the study of justice in social relationships. In K. Gergen, M. Greenberg, and R. Willis(Eds.), Social exchange: Advances in experimental and social psychology, Vol. 9, pp. 91-131).

Plenum, L. P. E., \& Williams, J. R. (2004). The social context of performance appraisal. Journal of Management, 30, 881-905 
Liden, R. C., Wayne, S. J., Kraimer, M. L., \& Sparrowe, R. T. (2003). The dual commitments of contingent workers: An examination of contingents' commitment to the agency and the organization. Journal of Organizational Behavior, 24, 609-625.

Martin, J., \& Harder, J. W. (1994). Bread and roses: Justice and the distribution of financial and socio emotional rewards in organizations. Social Justice Research, 7, 241-264.

Milkovich, G. T., \& Newman, J. M. (2005). Compensation (8th Ed.). Boston: McGrawHill

Miller, P., \& O’Leary, T. (1989). Hierarchies and American ideals: 1900-1940. Administrative Science Quarterly, 14,250-265.

Organ, D. W. (1988). Organizational citizenship behavior: Thegood soldier syndrome. Lexington, MA: Lexington Books.

Pfeffer, J., \& Langton, N. (1993). The effect of wage dispersion on satisfaction, productivity, and working collaboratively: Evidence from college and university faculty. Administrative Science Quarterly, 38, 382-407.

Pfeffer, J., \& Sutton, R. I. (2006). Hard facts, dangerous half-truths, and total nonsense: Profiting from evidence-based management. Cambridge, MA: Harvard Business School Press.

Richman, L. S. (1993, September 20). When will the layoffs end? Fortune, pp. 54-56.

Schoorman, F. D., \& Champagne, M. V. (1994). Managers as informal third parties: The impact of supervisor-subordinate relationships on interventions. Employee Responsibilities and Rights Journal, 7, 73-84.

Skarlicki, D. P., \& Latham, G. P. (1996). Increasing citizenship behavior within a labor union: A test of organizational justice theory. Journal of Applied Psychology, 81,161-169.

Skitka, L. J., Winquist, J., \& Hutchinson, S. (2003). Are outcome justice and outcome favorability distinguishable psychological constructs? A meta-analytic review. Social Justice Research, 16, 309-341.

Spencer, S., \& Rupp, D. E. (2006). Angry, guilty, and conflicted: Injustice toward coworkers heightens emotional labor. Paper presented at the Annual Meeting of theSociety for Industrial and Organizational Psychology, Dallas, TX.

Tyler, T. R., \&Blader, S. L. (2000). Cooperation in groups: Procedural justice, social identity, and behavioral engagement.

Viswesvaran, C., \& Ones, D. S. (2002). Examining the construct of organizational justice: A meta-analytic evaluation of relations with work attitudes and behaviors. Journal of Business Ethics, 38, 193-203.hiladelphia: Psychology Press. 